\title{
Leading Risk Factors for Cardiovascular Disease Among the Population of The North-West of Russia
}

\author{
Boris Fishman ${ }^{1 *}$, Alla Horoshevskaya ${ }^{1}$, Zurabov $\mathbf{V}^{1}$, Abdulin $\mathbf{A}^{1}$, Prozorova $\mathbf{I}^{1}$, Prozorova $\mathbf{N}^{1}$, \\ Mikhail Yukhno ${ }^{1}$, Svetlana Butrimova ${ }^{2}$, Oksana Lole ${ }^{3}$, Pavel Staricov ${ }^{3}$, Anton Dovgal ${ }^{3}$ and Raff \\ $S^{4}$
}

${ }^{1}$ Institute of Medical Education, Yaroslav-the-Wise Novgorod State University, Russia

${ }^{2}$ Regional Clinical Hospital, Russia

${ }^{3}$ Central Clinical Hospital, Russia

${ }^{4}$ Kuban State University, Russia

*Corresponding author: Boris Fishman, Institute of Medical Education, Yaroslav-the-Wise Novgorod State University, Veliky Novgorod, Russia.

To Cite This Article: Boris Fishman. Leading Risk Factors for Cardiovascular Disease Among the Population of The North-West of Russia. Am J Biomed Sci \& Res. 2019 - 3(6). AJBSR.MS.ID.000722. DOI: 10.34297/AJBSR.2019.03.000722

Received: June 26, 2019 | Published: July 09, 2019

\begin{abstract}
Arterial hypertension and coronary heart disease cause huge damage to the health of the population, being the strongest risk factor for the excess mortality of the population. The results of many prospective studies conducted in the country show a high prevalence of these FR and prove their influence on the indices and dynamics of CVD mortality [1,2]. The concept of RF became the scientific basis for prevention, reducing morbidity and mortality from CVD and is widely used in practical work [3-5].
\end{abstract}

Keywords: Risk factors; Cardiovascular diseases; The population of the North-west of Russia

\section{Introduction}

The study of regional features of the RF in the conditions of over-mortality of the population is actual, which determined the subject of this study. One of the important achievements in the field of cardiology in the second half of the 20th century was the discovery of factors affecting the development and progression of CVD, which received the name of risk factors (RF). At the same time, it is necessary to take measures aimed at changing the way of life and correction of other risk factors or diseases. The analysis, based on non-fitting criterion, proves possible impact of such risk factors as obesity, smoking, alcohol abuse (these risk factors are seen more often among younger population), marital status (especially widowers and widows), job dissatisfaction and stress, on the development of cardiovascular diseases in the population. However, high level of educational qualifications in the population allows having special courses for hyper-tensive individuals where technological intervention acts as a basic method of primary prevention of hypertension and its complications $[6,7]$.

\section{Methods}

In the period 2012-2014, one-moment, two-stage (cardiologic and psychometric screening), a selective, epidemiological study (cross-sectional study) was conducted to detect arterial hypertension (AH) and its risk factors (RF) among adults $[1,8,9]$. Based on 1\% of the sample, 4578 respondents (2606 men and 1972 women) were selected. As a survey, the standard questionnaire of the GNITS PM was used. Population sampling was formed on the basis of name-based voter lists using a random number method in a computer variant in a non-recurring way with a response rate of $73.1 \%$ (male) and $76.0 \%$ (female). The method of selecting respondents was based on the settlement-nuclear type of the stratified sample. The age composition of the population, taking into account gender differences, was divided into 6 decades corresponding to the European age classification.

In the process of mathematical analysis of the data obtained, we applied the methods of descriptive statistics; dispersive one- and multifactor analyzes; correlation-regression analysis based on the matrix method and multiple analysis with a selection in this case of the regression equation model and an evaluation of the results obtained on the basis of the Gaussian distribution; multidimensional statistical methods, including cluster and factor analysis. Statistical pro-cessing of data was carried out using the program STATISTICA 10, Stat Soft. License number AGAR207F394525FA-6. 


\section{Results}

An analysis of the mortality of the population showed that $62 \%$ of the region's population dies from cardiovascular pathology. The comparative analysis taking into account the sex of risk factors (FF) revealed a number of statistically significant differences. Thus, among all FF, statistically significant differences were revealed by the factor of diet compliance at $t=7.27(\mathrm{P}<0.0001)$ and $\mathrm{t}=-2.82$ ( $\mathrm{P}<0.0156)$ when assessing non-compliance with the diet. The value of the inter-quartile range $(\mathrm{QR})$ according to non-parametric statistics was when assessing compliance with the diet Me 28.8 (at $26.3 \div 30.8$ ) and Me 70.7 (at $60.7 \div 71.3$ ) with assessment of non-compliance with the diet. It was found that compliance with the diet is more typical for women within $30 \%$. At the same time, the diet is not respected regardless of sex in the range of $60-70 \%$ of respondents. This fact was subsequently reflected in the frequency of dyslipidemia among the population [10-12].

Parametric analysis revealed significant differences in the frequency of tobacco smoking, taking into account gender differences. Thus, $62.4 \%$ of respondents never smoked at $\mathrm{t}=4.91(\mathrm{P}$ $<0.0004$ ). Nonparametric analysis showed that $59 \%$ of respondents never smoked with a $\mathrm{QR}$ value of $52.6 \div 69.8$. At the same time, the maximum values for this indicator were more than $80 \%$. The high Gaussian density is 17.1 [13-15].

When assessing the use of vodka in the amount of 50-100 $\mathrm{ml}$. the significance of the differences was at $\mathrm{t}=-3.56(\mathrm{P}<0.004)$. Nonparametric analysis showed that $12 \%$ of the population consumed the mentioned quantity of vodka at the value of QR $7.4 \div$ 12.9 and the Gaussian density was only 5.5.

The highest significance of gender differences was noted in assessing motivation for work (the desire to work). In this case, $13.3 \%$ of women note a lack of motivation and a moderate motivation of $34.5 \%$ (respectively, M 13.3 for SD $4.3 \pm 3.7$ and M 34.5 for SD $15.0 \pm 12.1$ ). Among men this indicator is equal to $\mathrm{M}$ 12.4, respectively, with SD $2.9 \pm 1.9$ and M 31.5 with SD $15.2 \pm$ 13.2. Non-parametric data of lack of motivation accounted for the median value among women 11.1, respectively, with QR $9.3 \div$ 16.9; among men, Me 12.7 with a QR value of $11.5 \div 15.0$ and a Gaussian density of 3.5 . In the second parameter, the evaluation of non-parametric data showed that there is a moderate median motivation for women among 31.7, respectively, with a QR value of $18.6 \div 51.4$, with a Gaussian density of 32.8; among men, Me 33.7 with a $Q R$ value of $14.6 \div 47.4$ and a Gaussian density of 32.7 [1618]. Thus, it was found that the lack of motivation for work in men is more manifested than in women.

In assessing moderate dissatisfaction with family relationships, a gender difference was found at $\mathrm{t}=2.64$ ( $\mathrm{P}<0.0217$ ). Among women, M 24.6\% with SD $4.5 \pm 3.3$; among men, M 18.4\% with SD $4.1 \pm 3.1$. Nonparametric analysis showed that non-satisfaction with family relationships among women Me 25.0\% with QR 20.9 $\div 26.6$ and a Gaussian density of 5.7; respectively among men Me $19.5 \%$ with QR $14.4 \div 20.3$ and Gaussian density equal to 6.3 .

Thus, a higher level of moderate dissatisfaction in the family in women was revealed. For the rest of the indicators, statistically significant gender differences are absent. The frequency of prevalence of $\mathrm{AH} 1$ degree among men is 30\%; 2 degrees - $27 \%$ and 3 degrees 13\%. Among women, respectively, 27.28 and 13\%. The highest prevalence of hypertension does not depend on the age and sex of the respondents and are in the 95\% range of the interval. Attention is drawn to the high proportion of the frequency of hypertension in the younger age groups irrespective of sex and reaching almost $50 \%$ in the age group of 80 years and older. In older age groups $\mathrm{AH} 2$ and 3 degrees is dominant. The proportion of AHs 2 and 3 in the older age group is slightly higher among women $[19,20]$.

The highest significance of differences taking into account gender characteristics with-out taking into account the degree of hypertension is presented in the age group of 70-79 years $(t=-3.63$ at $\mathrm{P}=0.0109)$ and in the age group 80 years and older $(\mathrm{t}=-3.10$ $\mathrm{P}=0.0211)$.

Thus, for the population the most common degree of $\mathrm{AH}$ is 1 and 2 degrees. At the same time, the second and third degree has gender characteristics and they are characteristic for middle and older age groups irrespective of sex. The degree of AH in women is shifted to the 1 age group in the direction of $\mathrm{AH}$ weighting [21].

The population of the Novgorod region is characterized by the presence of obesity regardless of gender, with an emphasis on the average age groups. The number of patients is com-parable with the number of patients in the Northwest of Russia.

The non-parametric analysis carried out on the basis of the Friedman criterion and Kendall concordance showed that the family status of the respondents is gendered. Thus, the magnitude of the interquartile range in terms of the state of the marriage among the men has higher values for 75 quartiles. At the same time, the median environment of QR gravitates toward the upper boundary. Taking into account the value of the Gaussian density, it can be seen that men often live separately, although the minimum value for individual men can be zero.

Thus, the number of men who do not work by age exceeds that of women. In men, the value of QR is significantly higher than in women of 75 quartiles. Introduction to the age gradient analysis showed that half of the respondents in the age groups 40-49 and 70-79 years, as well as 80 years and older, do not work due to illness. In the 60-69 age group, women have a high proportion of the unemployed due to illness. Thus, it can be seen that men cannot continue to work after reaching retirement age, which subsequently affects the social status of respondents.

The descriptive analysis showed that $62 \%$ of women (SD $11.2 \pm$ 8.2) and $33.2 \%$ of men (SD $11.2 \pm 8.6$ at $\mathrm{P}=0.7747$ ) never smoked. Nonparametric data indicate that $59 \%$ of women have never smoked (QR $52.6 \div 69.8$ ) and $31.1 \%$ of men (QR 26.3 $\div 43.9$ ). $14.1 \%$ of women (SD $8.5 \pm 6.3$ ) and $25.8 \%$ of men (SD $13.4 \pm 10.7$ with $\mathrm{P}=$ $0.0756)$ have now quit smoking. Non-parametric data indicate that $15.1 \%$ of women (QR $6.6 \div 17.8$ ) and $24.2 \%$ of men (QR $9.8 \div 37.9$ ) have quit or do not smoke now. $25.6 \%$ of women (SD $7.7 \pm 28.8$ ) and $36.8 \%$ of men (SD $19.9 \pm 16.8 \mathrm{P}=0.7747$ ) smoke now. The number of cigarettes per day is statistically homogeneous and is up to 10 cigarettes per day regardless of gender. 
Cluster analysis showed that women in the age group 20-29, 30-39, 40-49 years and after 70 years have never smoked; men differ in age peculiarities with a frequency different in each age group. All women age groups until 70 years smoke now; men - only in senior age groups.

Smoking cessation is not a dominant feature in any age group, regardless of gender. The rate of cigarette use in the female population is slightly higher, especially in the younger age groups. Thus, the analysis indicates the dominance of this harmful habit in female subpopulation with a sharp rejuvenation of the habit $[22,23]$.

Conducted descriptive analysis has shown that $44.3 \%$ of women (SD 9.6 \pm 7.3 ) and $34.8 \%$ of men (SD 18.2 $\pm 14.6 \mathrm{P}=0.2423$ ) have been drinking no alcohol. Nonparametric data indicate that $45.9 \%$ of women (QR 36.5 $\div 51.9$ ) and $25.4 \%$ of men (QR 23.9 $\div 52.4$ ) have been drinking no alcohol. $2.6 \%$ and $4.3 \%$ of women (SD $2.4 \pm$ 2.2 and SD $4.2 \pm 3.0$ ); $1.7 \%$ and $7.9 \%$ of men (SD $1.6 \pm 1.4$ and SD $3.9 \pm 3.1$ when $\mathrm{P}=0.4070$ and when $\mathrm{P}=0.1268$ ) intake respectively excessive alcohol (daily or more $100 \mathrm{ml}$. of vodka).

Nonparametric data indicate that $6.4 \%$ of women intake excessive alcohol on the maximal values of QR in more than $100 \mathrm{ml}$ of vodka within $12.8 \%$; men $-3.7 \%$ of more than $100 \mathrm{ml}$. of vodka in the range of $12.4 \%$. Distribution according to age groups shows that daily consumption of alcohol is true for the age groups of 50$59,30-39$, and 40-49 years for men and 70-79 years for women with the amount of alcohol over $100 \mathrm{ml}$. of vodka for men of older age groups and women in the age groups 50-59 and 60-69 years.

Thus, there is feminization of the harmful habit characteristic of the middle female age groups and male older age groups. The noted fact correlates with the index of the widow among the population at Spirmen correlation coefficient $=0.79$.

When considering the index of physical activity (PA), it was found that limited physical activity is characteristic for 28-29\%, moderate - for $62-67 \%$ and significant for $20-23 \%$ of respondents.

The significance of gender-specific differences, excluding the severity of physical activity, is noted in the age group of 80 years and older $(\mathrm{t}=-3.95$ at $\mathrm{P}=0.0168)$ for minimum indicators and $\mathrm{t}=-4.42$ at $\mathrm{p}=0.0115$ for maximum indicators. The conducted descriptive analysis showed that limited physical activity was $24.6 \%$ among women (SD $15.6 \pm 12.9$ ) and $22.8 \%$ among men (SD 19.9 15.7 at $\mathrm{P}=0.8439$ ). Significant physical activity was $21.5 \%$ among women (SD $18.2 \pm 13.8$ ) and $16.1 \%$ among men (SD 13.0 10.1 at $\mathrm{P}=$ $0.5393)$.

Nonparametric data indicate that $24.1 \%$ of women have limited

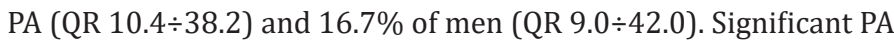
is characteristic for $17.5 \%$ of women (QR $7.1 \div 31.7$ ) and $16.2 \%$ of men (QR 2.8 $\div 30.9$ ). Limited PA is typical for women in the age group of 60-69, 70-79 years, for men in the age group of 50-59 and 60-69 years. A significant PA is characteristic of 60-69 years and older among women and 50-59, 60-69, 70-79 years among men.

Thus, limited PA is characteristic of older age groups regardless of gender, significant PA - for middle and younger age groups.
The conducted descriptive analysis showed that $40.2 \%$ of women (SD $2.8 \pm 2.2$ ) and $28.9 \%$ of men (SD 3.0 \pm 2.2 at P $=0.0001$ ) were on diet. $55.0 \%$ of women (SD $3.4 \pm 2.9$ ) and $65.4 \%$ of men (SD $9.2 \pm 6.7$ with $\mathrm{P}=0.0156$ ) do not follow the diet.

Nonparametric analysis revealed that $41.0 \%$ of women with value $Q R$ 37.0 $\div 41.5$ and $28.8 \%$ of men with the value of $Q R$ $26.3 \div 30.8$ do not follow the diet. $53.8 \%$ of women with the value QR $51.4 \div 58.1$ and $70.7 \%$ of men with the value of QR $60.7 \div 71.3$ do not follow the diet. The maximum values were $59.9 \%$ for women and $71.8 \%$ for men.

Thus, non-compliance with the diet is a dominant risk factor for respondents regardless of gender, with the prevalence of male subpopulation. The conducted descriptive analysis showed that $6.2 \%$ of women (SD $3.1 \pm 2.2$ ) and $4.3 \%$ of men (SD $2.3 \pm 1.9$ at $\mathrm{P}$ $=0.2103$ ) experienced daily stress. Nonparametric analysis has shown that $5.8 \%$ of women at the value QR $4.0 \div 8.4 ; 4.7 \%$ of men at the value of $\mathrm{QR} 2.0 \div 5.9$ experienced daily stress. The maximum values in women were $11.6 \%$, in men $8.2 \%$.

The prevalence of anxiety and depression among the population has clearly expressed gender character and is correlated with the prevalence level of hypertension among the population. We do not exclude the combination of arterial hypertension and anxietydepression syndrome as a single syndrome complex. The noted should determine the possibility of AH treating with beta-blockers, as drugs that can cause depression in patients, thereby weighting the course of $\mathrm{AH}$ disease.

The importance of differences taking into account gender features and without taking into account the severity of emotional stress is noted in the age group of 80 years and older $(\mathrm{t}=-2.44$ at $\mathrm{P}=$ 0.0407 ) for maximum performance. No differences were found in other parameters.

\section{Discussion and Conclusion}

To assess the possibility of falling ill with AG respondents, we used the criterion of dis-agreement (OR). As our study showed the calculations of the disagreement criterion showed that the chances of women getting $\mathrm{AH}$ are the highest in the age group of 50-59 years (OR 22.16 at $\mathrm{P}=0.05$ and $\mathrm{QR} 8.87 \div 55.41$ ). Among men, this criterion is slightly lower, and it is the highest in the age group of 60-69 years (OR 11.67 at $P=0.05$ and $Q R 2.9 \div 46.96$ ). In other age groups, the criterion of disagreement has no statistically significant gender differences.

Thus, it is proved that the chances to get $\mathrm{AH}$ are higher among women. Men's chances are 1.9 times lower than women's and more susceptible with the older age group. Obviously, such a phenomenon is associated with the previously recorded phenomenon of supermortality among men in the age group of 50-59 years.

Calculations of the disagreement criterion showed that the chances to get $\mathrm{AH}$ for women with excessive $\mathrm{BMI}$ are the highest in the age group of 40-49 years (OR 1.97 with $P=0.05$ ). In assessing obesity, $\mathrm{OR}$ values are increased to 3.68 at $\mathrm{P}=0.05$. Among men, this criterion is slightly higher and it is the highest in the age group of 60-69 years (OR 2.58 at $\mathrm{P}=0.05$ ). In assessing obesity, OR values 
are increased to 3.2 in the $60-69$ age group and to 3.27 in the 30 39 age group with $\mathrm{P}=0.05$. In other age groups, the criterion of disagreement has no statistically significant gender differences. Attention is drawn to the exceedance of the indicator regardless of age group among men both in BMI and in obesity. Assessing the chances of $\mathrm{AH}$ development in abdominal obesity, it was found that this type of obesity is gender-independent for the age group of 6069 years - in women 2.48; in men -2.32 at $\mathrm{P}=0.05$. In general, for men and women, OR values for this type of obesity are 1.82 and 1.91 , respectively.

Thus, it is shown that abdominal obesity increases the chances of $\mathrm{AH}$ in the population within 2 times. Assessing the impact of family status on the risk of $\mathrm{AH}$ in the population it was found that marital status has an impact on the possibility of development of $\mathrm{AH}$ in the population. It is shown that in almost every age group, the chances of falling ill with $\mathrm{AH}$ among married women range from 1.7 to 6.33; among married men - in all age groups, with the exception of the age group 30-39 and 50-59 years. In general, the odds ratio for married men and women is within 3.2 at $\mathrm{p}=0.05$ and $\mathrm{QR}$ $2.07 \div 4.95$ and 3.52 at $\mathrm{p}=0.05$ and $\mathrm{QR} 2.27 \div 5.46$ respectively. The chances are higher in married men in the age group of $60-69$ years (OR 3.14 at $\mathrm{p}=0.05$ and $Q R \quad 0.4 \div 24.42$ ) and among women in the age group of 70 years and older (OR 6.33 at $p=0.05$ and $Q R 0.63 \div 63.64$ ). In assessing the status of divorced, the value of OR is significantly higher than that of women in comparison with men (respectively, OR 4.62 at $\mathrm{p}=0.05$ and $Q R 2.65 \div 8.03$ and 0.85 at $\mathrm{p}=0.05$ and $Q R$ $0.44 \div 1.62$ ).

Significant changes were observed in all age groups in the evaluation of widowhood status. Thus, among men, the values of the odds ratio are 7.47 at $p=0.05$ and $Q R$ 3.57 $\div 15.6$; among women -24.86 at $\mathrm{p}=0.05$ and $\mathrm{QR} 13.91 \div 44.43$.

Thus, it is established that marital status has a direct significant impact on the incidence of $\mathrm{AH}$ in population.

When evaluating the odds ratios of the influence of smoking on the ability of the $\mathrm{AH}$ disease it is established that the frequency of smoking is significant only in the age group of 20-29 years for males (OR 2.97 at $\mathrm{P}=0.05$ ) and in the age group of $30-39$ years in women (OR 3.72 at $\mathrm{P}=0.05$ ).

When evaluating the odds ratios of the effect of alcohol consumption on the ability of $\mathrm{AH}$ disease it is established that a significant impact of alcohol consumption on the ability of $\mathrm{AH}$ developing does not exist [24-26].

Low physical activity affects the development of $\mathrm{AH}$ only in women in the age group of 20-29 years (OR 2.87 at $\mathrm{P}=0.05$ ), 4049 years (OR 1.59 at $p=0.05$ ). In men, the test value is well below 1 , indicating no influence. The data obtained indicate a significant increase in pathology among the population of the region compared with the data of the sample survey 2003-2004 [2,13,18,19,27].

The conducted analysis on the basis of the disagreement criterion proves the possible in-fluence on the development of cardiovascular disease among population such RF as obesity, smoking, alcohol consumption (in the background of the rejuvenation data of $\mathrm{RF}$ ), marital status (especially the status of widowhood), dissatisfaction with work and stress $[8,9,17,20,28]$. However, the presence of a high level of educational qualification in the population allows to use actively "schools of hypertensive people" for technological intervention as a basic means of primary prevention of $\mathrm{AH}$ and its complications.

\section{Disclosures}

All authors have not disclosed potential conflicts of interest regarding the content of this paper.

\section{References}

1. Ageev FT (2004) Rasprostranennost AH v Evropeiskoi chasti Rossii / Ageev FT, et al. 2003 г, Cardiology 44 (11): 50-53.

2. (2014) VOZ - Situation with NIZ in pages.

3. Gundarov IA (1995) Pochemu umiraut v Rossii I kak nam vigit M.

4. Gundarov IA, Polesskii VA (2014) Upravlenie individualnimi rezervami zdorovia:bnovaia strategia profilakticheskoi medicine, Zdravoochranenie Rossii.

5. Gundarov IA, Polesskii VA, Vlasov VV (2004) Arterialnaia gipertenzia factor riska ili indicator riska? Obchestvennoe zdorovie I profilaktika zabolevanii 5: 12-19.

6. Deev AD, Britov AN, Oganov RG (1999) Associacia arterialnaia gipertenzia I socialno-demograficheskich pokazatelei na primere Moskovskoi oblasti Ros. Kardiologicheskii journal 4: 39-40.

7. Gukovskii GS (1997) I soavtori Arterialnaia gipertenzia: Epidemiologicheskaia situacia d Rossii I drugich stranach, Rus med journal 9: 551-558.

8. Kornileva IV, Oganov RG, Ivanov KI (2004) Mediko-socialnii faktori formirovania "serdechno-sosudistogo zdorovia" naselenia. Profilaktika zabolevanii I ukreplenie zdorovia 4: 3-6.

9. Melentev IA, Dmitriev DV (1995) Izuchenie psichologicheskich aspektov adaptacii bolnich IBS the study of the psychological aspects of adaptation of patients with coronary artery disease. Riscometria I adaptacia v medicine p. 53-54.

10. Oganov RG (2001) Arterialnaia gipertenzia I ee vklad v smertnost ot serdechsosudistich zabolevanii / Oganov RG, et al. (Eds) Profilaktika zabolevanii I ukreplenie zdorovia 4:11-15.

11. Oganov RG, Olbinskaia LA, Smulevich AB (2004) Depressii I rastroistva depressivnogo spekta v obchemedicinskoi praktike. Perultati programmi Kompas Cardiology 1: 48-54.

12. Oganov RG (1998) Vliianie kurenia na smertnost ot chronicheskich neinfekcionnich zabolevanii po rezultatam prospectivnogo issledovania. Profilaktika zabolevanii I ukreplenie zdorovia 3: 13-15.

13. Oganov RG (2003) Faktori riska I profilaktica serdechsosudistich zabolevanii. Kachestvo gizni Medicine 2: 10-15.

14. Chasov EI, Oganov RG (2007) Klinico-epidemiologicheskaia programma izuchenia depressii v kardilogicheskoi praktike: e bolnich s AH i IBS (Koordinata), Perultati mnogocentruvogo issledovania. Kardiologia 47(3): 28-37.

15. Chalnova SA (1999) Faktori riska serdechsosudistich zabolevanii I pokazateli ogidaemoi prodol-gitelnosti gizni ynaselenia Rossii. Avtoreferat diss M.

16. Choinière R, Lafontaine P, Edwards AC (2000) Distribution of cardiovascular disease risk fac-tors by socioeconomic status among Canadian adults. CMAJ 162(9 Suppl): S13-24

17. EUROASPIRE II Group (2001) Lifestyle and risk factor management and use of drug therapies in coronary patients from 15 countries: principal 
results from EUROASPIRE II Euro Heart Survey Programme. Europ Heart J 22(7): $554-572$.

18. EUROASPIRE III (2008) K Kotseva, et al. (Eds) Eur J Cardiovasc Prevent, Rehabilit 16(2): 121-137.

19. Gliksman MD, Lazarus R, Wilson A, Leeder SR (1995) Social support, marital status and liv-ing arrangement correlates of cardiovascular disease risk factors in the elderly. Social science \& medicine 40(6): 811814.

20. Oganov RG (2002) Znachenie cardiovascular disease I drugich chronicheskich zabolevaniq dlia zdorovia ynaselenia Rossii. Oganov RG, et al. (Eds), Profilaktika zabolevanii I ukreplenie zdorovia 2: 3-7.

21. Chalnova SA, Deev AD, Oganov RG (2005) Faktori, vlijauchii na na smertnost ot cardiovascu-lar disease d rossiiskoi populacii. Kardiovascular terapiia I profilaktica 1: 4-9.

22. Kilander L, Berglund L, Boberg M, Vessby B, Lithell H (2001) Education, lifestyle factors and mortality from cardiovascular disease and cancer. A 25-year follow-up of Swedish 50-year-old men. International Journal of Epidemiology 30(5): 1119-1126.
23. Luepker RV, Rosamond WD, Murphy R, Sprafka JM, Folsom AR et al. (1993) Socioeconomic status and coronary heart disease risk factors. Circulation 88(5 Pt 1): 2172-2179.

24. Perkins Porras L, Whitehead DL, Steptoe A (2006) Patients' beliefs about the causes of heart disease: relationships with risk factors, sex and socio-economic status. Europ J Cardiovasc Prev Rehab 13(5): 724 -730.

25. Schepin OP, Belov VB, Schepin VO (2006) Osobennosti dinamiki smeptnosti naseleniia Rus-sia. Problemi socialnoj gigieni, zdravoochranenia I istorii medicine 6: 6-10.

26. European Society of Hypertension-European Society of Cardiology Guidelines Committee (2003) Committee 2003 European Society of Hypertension - European Society of Cardiology guidelines for the management of arterial hypertension. J Hypertens 21(6): 1011-1053.

27. Whelton P, Brancati F (1993) Hypertension management in populations. Clin Exp Hypertension 15(6): 1147-1156.

28. Corrao G, Rubbiati L, Bagnardi V, Zambon A, Poikolainen K (2000) Alkogol and coronary heart disease: a meta-analysis. Addiction 95(10): 1505-1523. 